\title{
Innovation networks effects simulation models
}

\author{
Olha Prokopenko $^{1}$, Vitaliy Omelyanenko ${ }^{2}$, T. Ponomarenko ${ }^{3}$, O. Olshanska ${ }^{4}$ \\ ${ }^{1}$ Center for European Education and Research, International Humanitarian University \\ ${ }^{2}$ Department of Business Economics and Administration, Sumy State Pedagogical University named after A.S. Makarenko \\ ${ }^{3}$ Department of International Economics, Accounting and Finance, Yu. Buhai International University of Science and Technology \\ ${ }^{4}$ Faculty of Economics and Business, Kyiv National University of Technologies and Design
}

\section{Article Info}

Received Feb 27, 2019

\section{Keyword:}

Innovation network

Model

Technology transfer

Effect

Analytics

Innovation network agent

Technology transfer network

\begin{abstract}
In current conditions it becomes necessary to develop guidelines for development of the national innovation systems and assessing their role in sustainable national socio-economic development. In the conditions innovation development strategies should be focused on ensuring the competitiveness of economic entities, which can be done through innovation networks. The study enhances academic understanding of the factors of innovation transformation based on innovation networks, designed to ensure the involvement of large number of agents to contribute to the implementation of structural changes. In this paper authors analyze the main indicators of innovation networks impact and investigate the main aspects of innovation networks effects simulation. The hypothesis of the study deals with the assumption that the innovation development of the economic system at the present stage, in addition to stimulating the innovative activity of existing entities, deals with the formation of network structures. This research addresses the indicators for networks modeling by developing and testing a series of points indicating how networks affect economic growth. The foregoing discussion has attempted to innovation networks innovation potential assessing methodology based on indicators of the quantitative composition and dynamics of innovation potential to substantiate the viability of this organizational form in developing sectoral policies and technological priorities has been developed. The developed economic and mathematical model of innovation management network leads us to the conclusion that allows predict changes and form a targeted impact on factors when creating new intersectoral structures in order to increase the volume of innovation products.
\end{abstract}

\section{Corresponding Author:}

Vitaliy Omelyanenko,

Department of Business Economics and Administration,

Sumy State Pedagogical University named after A.S. Makarenko,

87 Romenkska, Sumy, 40002, Ukraine

Email: omvitaliy@gmail.com

\section{Introduction}

The transfer of competition into the high-tech sphere predetermines a significant expansion of innovation factor in economic system through involvement of number of new participants. New mechanisms for expanding the space of innovation development are based on the creation of innovation networks. Therefore the significance of current research consists in expanding scientific understanding of transformation processes taking place in economic system, which determine the need to stimulate innovation activity and the formation of new intersectoral structures and infrastructure facilities [24]. What we usually have in mind when we talk about network effect or network externality is the name that the user of a product or service provides for the value of this product or service for other users. Several explanations of network effect and its simulation have 
been offered.

For modern innovation networks we can consider simulation of the tools which enable networks members to improve the innovation capabilities and knowledge exchange [8]. Research of innovation systems also has shown that corporative innovation processes are strongly interrelated with innovation activities in other organizations and firms [12]. This research [16] suggests that the collaboration level with different partners enhances innovation capabilities when the firm's managers have strong capacity of scanning and acquiring of external knowledge. Analysis, given in [5], shows that different types of innovations were positively affected by cooperation.

The paper [15] highlights empirical estimated innovation networks effects on innovation performance in French innovative service firms. Study [3] draws a large-scale study of 100 engineering firms, which are involved to different innovation networks. The hypotheses of study were tested with PLS structural equations modeling.

As a criteria of innovative development in modern conditions we can consider not so much the growth of activity in the field of innovation activity of economic entities in existing industries, but the development of technological areas that form the core of new technological order, based on the formation of new industries and inter-sectoral structures [14]. As a result, a truly innovation economy should be characterized by a set of transformation processes that arise as a result of the spread of new technologies in traditional areas of society, and the formation of new intersectoral structures, contributing to the transformation of the institutional components of the economic system and its transition to a new innovation level. In this regard study [30] presents model, which is based on the evolutionary mechanism and allows to estimate the response rate.

Study [25] has indicated that not all innovation networks dynamics factors are country specific. This allows considering the main issues of innovation network science, which is a tool to consider systems as a complex networks by mathematical abstraction for simulation of various innovation phenomena [29]. Study [23] presented a model with a group factors necessary for innovation networks managing (effectiveness, power, communication and R\&D efficiencies, harmony, coordination, trust). Some of these arguments have been formalized by [22] in simulation model, which helps to understand of innovation network nature with an interactions in knowledge creation and network cluster trajectories. Such trajectories make possible considering coordination game between firms in innovation network [36]. The evidence from given studies suggests variety of factors related to innovation networks simulation. These explanations are complementing each other and help to illuminate the phenomenon of innovation networks effects.

In this paper we shall analyze the main indicators of innovation networks development impact and investigate the main aspects of modeling of innovation networks effects. To answer this question, we'll take a closer look at such points:

- to form of theoretical approaches to study the processes of innovation development of economic systems and the mechanisms of their transformation;

- to identify the features and tools of innovative transformation of economic systems through the network structures formation;

- to develop a methodology for assessing the development of key areas of network structure formation using the methods of economic and mathematical modeling and analysis of statistical indicators;

- to develop the mathematical model for managing the innovative development of economic systems within the framework of the formation of network structures based on the significant indicators;

- to form a model for managing of the technology transfer network.

The hypothesis of the study deals with the assumption that the innovation development of the economic system at the present stage, in addition to stimulating the innovative activity of existing entities, deals with the formation of network structures. This research addresses the indicators for networks modeling by developing and testing a series of points indicating how networks affect economic growth.

\section{Material and methods}

In our previous studies [19;20-21] we have shown that innovation networks simulation allows to experiment with approaches to financing, managing, creating network structures, and selecting and structuring services as part of the implementation of state innovation strategies and private-public partnership projects.

The following methods can be used for determination the strategic role and effects of innovation networks based on network simulation: 
- adapted methods of decision-making based on the performance indicators optimization;

- comparative analytics methodology and system-evolutionary approach for studying the innovation networks role in different periods in terms of groups of countries;

- technological analysis methods for determining technological dynamics and technological trajectory of innovation networks technologies in different dimensions;

- methods of innovation networks strategic and inter-industry high-tech complexes development analysis;

- methods of finding innovative trajectories of innovation networks development and innovation development policy analysis methods.

From the whole variety we can identify three main approaches that define the purpose of innovation networks simulation:

1. Commercialization of technology projects to obtain short-term returns (for example, by creating a new company and transferring to it a part of the assets, the so-called "spin-off"). In this case, all the variety of investment analysis is used.

2. Building local innovation systems (ecosystems) to obtain financial returns in the medium and long term (for example, creating connections in the business community).

3. Development of the market of innovative services through building up entrepreneurial potential, transparency and efficiency of the market of service providers and raising the awareness of representatives of small and medium-sized businesses.

There are a number of evaluation methods related to actual network mechanisms. For example, the participation of organizations in joint projects for the implementation of research and development, in the total number is reflected through the Index of participation of organizations in joint projects. At the macro level, there are also a number of international assessments of network readiness and country involvement. Selected network indicators were included to Global Innovation Index study methodology [4]. According to Global Innovation Index 2018 report the technological cooperation and innovation networks as a tool of such cooperation are considered as an important elements of modern innovation ecosystems.

Currently, the scientific literature indicates a number of methods in assessing the socio-economic effects of innovation networks.

One of the most common ways is an autonomous study of various statistical indicators that quantitatively reflect certain parameters of socio-economic system [2; 27] and changes as a outcome of the functioning (creation) of an innovation network (most often a cluster). This line of research can be used to develop a system of indicators for estimation of the quality (dynamics) of network interaction in the innovation system.

For the analysis of spatial-network interaction of the subjects of innovation system and the development of effective policy in its stimulation, a method, that allows obtaining information about the specific level of such interaction, is needed. This technique can be built on an integral approach and includes the definition of a special integral index that combines the main, most significant components, reflecting various aspects of interaction between the agents of the innovation system.

Currently, more and more experts confirm the need for a combination of sociological and economic approaches in the analysis of network relations.

In the paper [13] theories of complex adaptive systems based on the multi-agent modeling and adaptive intelligent agents, smart simulation, statistical methods, expert systems, analytical hierarchy of processes simulation, hybrid decisions support approach. In given study these methods are integrated for innovation network analysis problem. Also it can support the evolutionary process of decisions making within the simultaneously open and dynamic environment of innovation activity.

Table 1 illustrates the main approaches for networks analytics, based on [26], and we have shown the basic models, which can realize the given approaches in practice. For various purposes the combination of methods of different approaches should be used.

These approaches are based on the following prerequisites for the formalization of innovation networks effects:

- network paradigm of innovation process organization involves parallel actions, such as C-technology, and the creation of cross-functional teams, which requires capacity estimations;

- previous point causes presence of control points for decision-making and a tree structures;

- innovation networks allow using existing resources in alternative ways, since the innovation processes can be considered as a process of transforming the inputs (innovation development resources) into outputs (products, technologies, etc.);

- in the conditions of costs increasing at each subsequent stage of innovation process, the problems of finding 
promising ideas (both innovation ideas and organizational configurations), their proper evaluation and effective implementation within network coordination.

It should also be noted that the presented models are common and characteristic of economies at different stages of technological development.

In the construction of integral estimations various methods are used. One option is to form an integral indicator based on broader system of indicators, from which several primary indicators are selected. This method allows considering the various aspects of network interactions in the innovation system.

Table 1. Approaches and models of innovation networks analysis

\begin{tabular}{|c|c|c|c|}
\hline Approach & Main idea & Possibilities of application & Basic models \\
\hline $\begin{array}{l}\text { 1. Structural } \\
\text { approach }\end{array}$ & $\begin{array}{l}\text { It focuses on the geometric shape of } \\
\text { the network and the intensity of } \\
\text { interaction. Special attention is paid } \\
\text { here to the mutual location of } \\
\text { agents in the network and their } \\
\text { impact on the activities of other } \\
\text { agents and the nature of the } \\
\text { linkages between them }\end{array}$ & $\begin{array}{l}\text { Approach allows } \\
\text { considering the network in } \\
\text { the system of strong and } \\
\text { weak linkages and their } \\
\text { impact on the selection of } \\
\text { certain partners for the } \\
\text { network }\end{array}$ & $\begin{array}{c}\text { Simulation models, agent } \\
\text { modeling, optimization } \\
\text { models }\end{array}$ \\
\hline $\begin{array}{l}\text { 2. Resource } \\
\text { approach }\end{array}$ & $\begin{array}{l}\text { It considers the possibilities of } \\
\text { agents to attract individual and } \\
\text { network resources and differentiates } \\
\text { agents located in identical structural } \\
\text { positions of the network according } \\
\text { to their resources. }\end{array}$ & $\begin{array}{l}\text { Evaluation of possible } \\
\text { interactions based on } \\
\text { diagnosing the innovation } \\
\text { potential of agents in } \\
\text { network }\end{array}$ & $\begin{array}{l}\text { Simulation models, agent- } \\
\text { based modeling, } \\
\text { optimization models, } \\
\text { transaction cost estimation } \\
\text { models }\end{array}$ \\
\hline $\begin{array}{l}\text { 3. Regulatory } \\
\text { approach }\end{array}$ & $\begin{array}{l}\text { It studies the level of trust between } \\
\text { the subjects of interaction, as well } \\
\text { as the norms, rules and sanctions } \\
\text { that affect their behavior in the } \\
\text { network and the processes of } \\
\text { interaction. In this case, the roles in } \\
\text { which actors act in specific } \\
\text { relationships are analyzed. The } \\
\text { combination of individual and } \\
\text { network resources with the rules } \\
\text { and regulations in force in this } \\
\text { social network forms its "network } \\
\text { capital" }\end{array}$ & $\begin{array}{l}\text { Approach allows } \\
\text { exploring the company } \\
\text { from the standpoint of the } \\
\text { roles of the client supplier } \\
\text { at various stages of the } \\
\text { innovation process. } \\
\text { Determines which norms } \\
\text { and rules of relations } \\
\text { should exist between } \\
\text { subjects at a particular } \\
\text { stage }\end{array}$ & $\begin{array}{l}\text { Game methods, } \\
\text { knowledge assessment } \\
\text { models, interaction } \\
\text { potential models, } \\
\text { transaction cost } \\
\text { assessment models }\end{array}$ \\
\hline $\begin{array}{l}\text { 4. Dynamic } \\
\text { approach }\end{array}$ & $\begin{array}{l}\text { Focuses on changes in the network } \\
\text { structure over time. In the } \\
\text { framework of this approach, the } \\
\text { following research problems are } \\
\text { identified: the causes of the } \\
\text { formation of the network, the } \\
\text { change in the network s under } \\
\text { external influences }\end{array}$ & $\begin{array}{l}\text { Approach allows } \\
\text { considering the changes in } \\
\text { the network of } \\
\text { relationships and in the } \\
\text { activities of individual } \\
\text { agents after the } \\
\text { implementation of } \\
\text { individual projects }\end{array}$ & $\begin{array}{l}\text { Intellectual multi-agent } \\
\text { systems, evolutionary } \\
\text { modeling, neural } \\
\text { networks, models of } \\
\text { variant states }\end{array}$ \\
\hline $\begin{array}{l}\text { 5. Technological } \\
\text { approach }\end{array}$ & $\begin{array}{l}\text { Includes technology dynamics } \\
\text { analytics and agent modeling }\end{array}$ & $\begin{array}{c}\text { Analytical support of } \\
\text { innovation systems, } \\
\text { forecasting, technologies } \\
\text { monitoring, development } \\
\text { of roadmaps of } \\
\text { technologies and products }\end{array}$ & $\begin{array}{l}\text { Models of technological } \\
\text { dynamics, foresight } \\
\text { models, evaluation of } \\
\text { strategies and portfolios } \\
\text { of innovative projects }\end{array}$ \\
\hline
\end{tabular}

However, in this study, we propose to consider a number of particular indicators and approaches to assessing the various effects of the innovation network. 


\section{Theory}

For the evaluation of network interaction level in the innovation system within the framework of individual indicators we need to solve the following tasks:

- to determinate the real level of interaction between the subjects of the innovation system in the form of a specific numerical result, which will allow to compare with each other various variants of the innovation network;

- to analyze the dynamics of the development of the innovation system at a certain level for a certain period, i.e. the possibility of comparing different values of the level of interaction of network entities (sector, region, country, international project, etc.), but in different periods;

- to compile data-based typologies of innovation networks (scientific, technology transfer, production) in a scientific and practical study to improve the interaction in the innovation system;

- to compare the effectiveness of various measures of innovation policy (both intra-and inter-sectoral level), carried out in order to stimulate the development of interactions in the innovation system.

The first aspect of assessing the level of network interaction in the innovation system is associated with a quantitative \& effective analysis.

The network effect is a phenomenon of consumer value growth of a network as the number of nodes of this network grows. According to Metcalf Law, the network value grows in proportion to the square of the number of its users. Therefore we can consider increasing the importance (number and strength of effects) of network as the number of users and the number of connections between users increases. According to this definition, we can consider the relationship of both the socio-economic value of network and its innovative effects.

There are a number of effects known in economics that have a similar network nature:

1. The effect of scale: reducing the cost per unit of production in the distribution of fixed costs for a larger number of manufactured products.

2. Learning curve reflects the increase in performance when performing tasks as experience accumulates, which is a manifestation of the positive effect of improving the efficiency of operations due to the accumulation of information in the form of knowledge and the development of certain skills within the company structure.

3. An increase of transactions frequency [31] also leads to increasing the system efficiency due to specialization in certain operations.

The first aspect is related to the evaluation of quantitative indicators. Two brief examples might clarify this concept. The first example of such analysis can be found in project «Network Analysis and Simulation of Innovation Dynamics for new Key Technologies in the Energy Sector (InnoSEn)» («Development of tools for the analysis of innovation networks» subproject). This project includes knowledge dynamics analysis in networks based on key technologies implementing processes in energy transitions. Fig. 1 illustrates the example of innovation network analytics of joint battery research projects in Germany.

Such approach allows analyzing the structure of innovation network linkages and the innovation capacity of innovation network participants.

Therefore we can note that the technological trajectory analysis helps to consider interfirm innovation linkages as a technology transfer function in the framework of innovation networks. Analytics in this area can be done by application of geospatial visualizations, scientometrics and technology space mapping $[1 ; 6 ; 9]$, reflecting the distribution of elements of the innovation network in geographic space. The application of geoinformation systems and geospatial analysis for the innovation analytics is at an initial stage.

This quantitate aspect can be considered on Apple inventors network example. In 2007-2008 it has included 184 inventors and during 2009-2010 has grew to 617 and in 2011-2012 has eventually included 1167 inventors (Fig. 2). The connectivity in Apple's inventors has significantly increased in 2011-2012 and over $82 \%$ of all collaboration activities were done within the largest component in company's inventor network. Methods of visual representation of information about innovation processes allow of initial hypotheses about the regularities that necessarily require confirmation in the framework of further analytical studies based on the methods of quantitative analysis. Understanding general trends can help reveal the reasons of these trends. The paper [5] investigates Denmark's Innovation Network initiative and outlines that innovation network participation increases the labor productivity and total factor productivity by 7 and $13 \%$ respectively after 4 years. Additionally, innovation network participants program are about 5\% more likely to participate in innovation programs. These facts can explain the mechanism by which innovation network facilitates the productivity growth. 


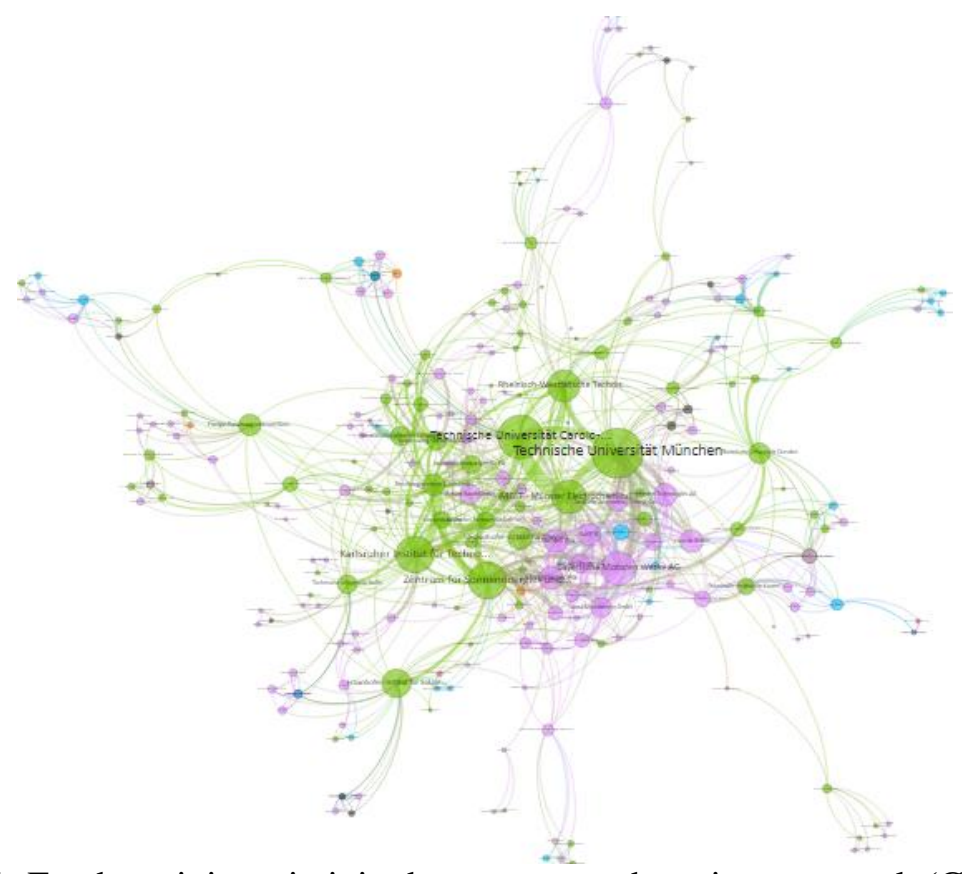

Figure 1. Funds recipients in joint battery research projects network (Germany)

(Notes: research institutions and universities are coloured with green,

industrial enterprises are coloured with pink and service providers are coloured with blue)
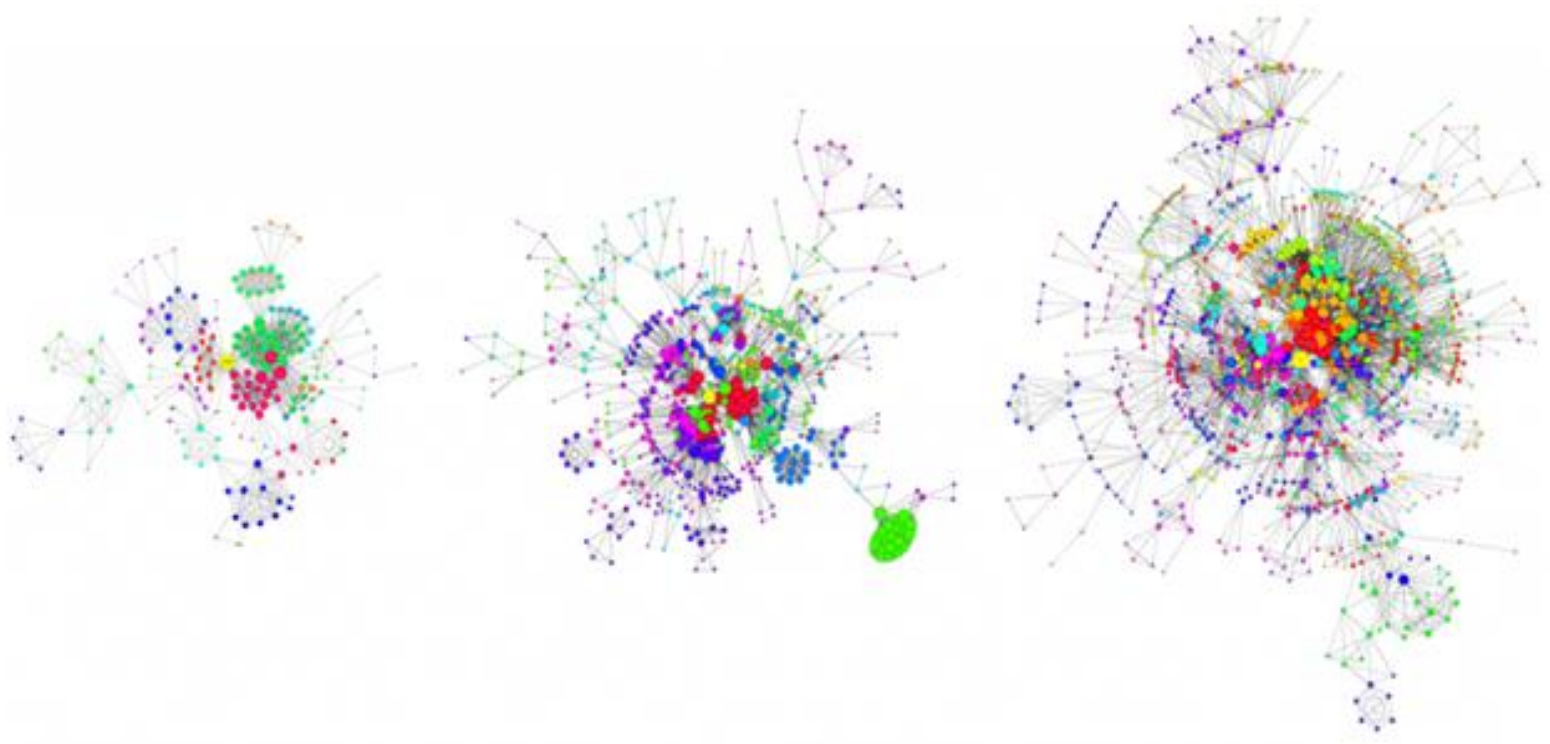

Figure 2. Evolution of Apple's inventor network

To obtain a more accurate assessment of innovation networks impact and to determine the results of the impact of large projects on macroeconomic indicators, a model complex can be used, which includes the following components [17]:

- two-period inter-sectoral optimization interregional model in two versions: the original model without the project and the modified model with the project;

- multi-period simulation model of the project, including the financial model and the economic model.

\section{Results}

In our opinion, processes in the innovation network can also be presented on the basis of the technology transfer criterion [18] as a set of flows (technological, financial, staff, information, material). In the course of 
the movement in the network from the stage of the idea of a new technology to the stage of implementation in the market of products produced by this technology, the size and intensity of these flows increase. Technology transfer framework includes different interacting entities and could be considered as an inter-organizational innovation network [8]. In addition, during the technology transfer in the network there are replacements of performers (network participants) that orient these flows (fundamental and applied science, research production and adaptation of technology, industrial production). In addition to the complete changes in the participants in technology life cycle, there is also a gradual change of performers, for example, the functional developers are added to the original developers.

Mathematically, the number of participants in the technology transfer innovation network should be written in the form of a logistic differential model (1):

$$
d y / d t=p y N^{-1}(N-y)-\alpha(t) y,
$$

where $y=y(t)$ - the number of participants in the technology transfer network at the time $t ; N$ - potential number of technology recipients; $p(p>0)$ - coefficient of growth of number of participants in transfer network; $\alpha(t)$ - coefficient of technology rejection by the participants in the transfer network.

Network innovation effects achieve a higher degree of efficiency due to the speed and timeliness of movement of information about technological features. Also, individual adaptation is highly pronounced in networks, due to which the networks significantly increase the internal labor productivity and the efficiency of attracting and using innovations.

To evaluate the impact of the network factor, consider the innovation progress models (Table 2). It is worth noting that the evaluation of the potential of the innovation network, in particular its cross-sectoral aspect and some applied tasks [32 - 37], is not considered sufficiently in them.

Table 2. Network impact in innovation progress models

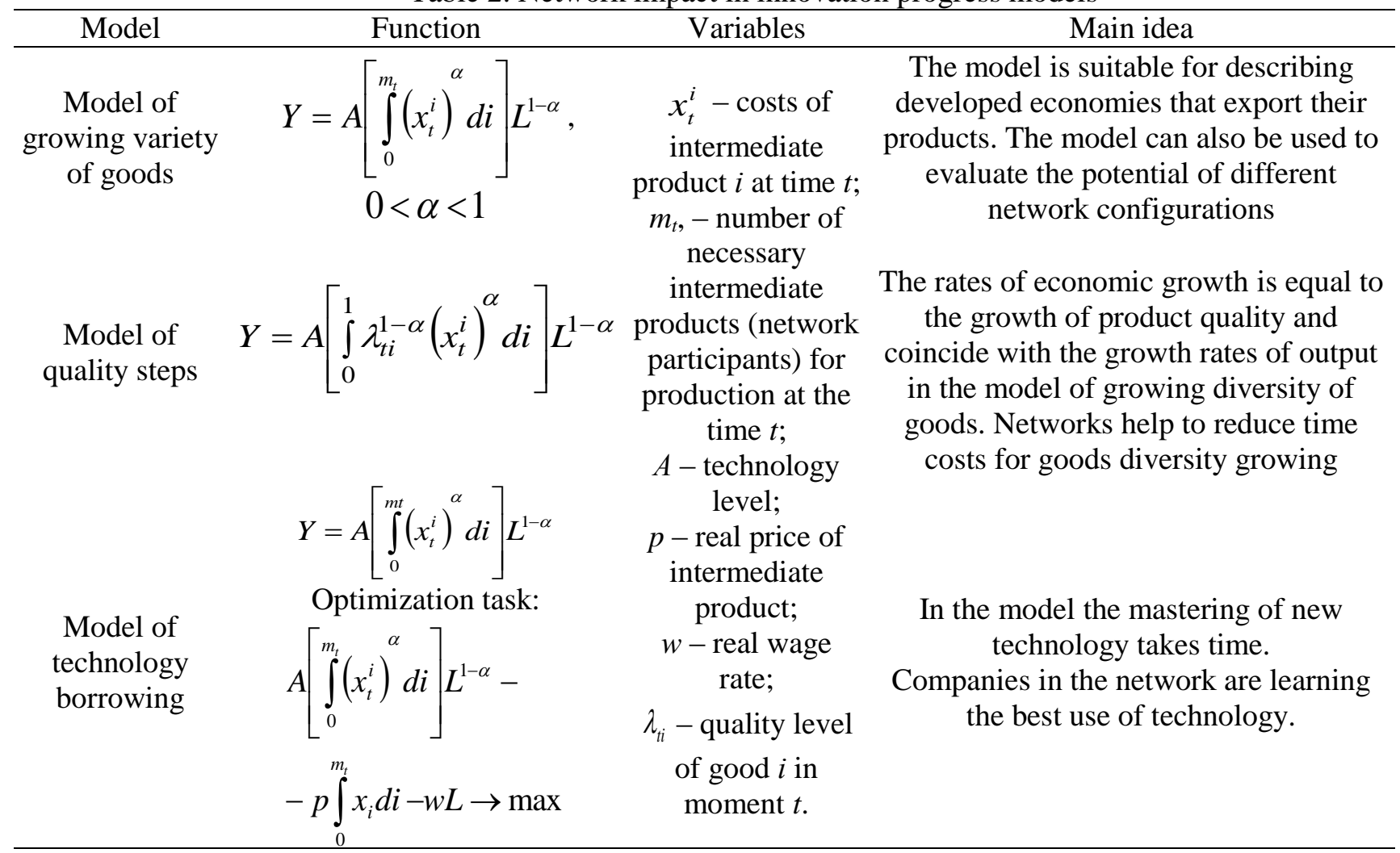

The standard model suggests, that innovation network are based on resources of its individual participants (agents). Therefore each element of innovation network can characterized by a set of characteristics: structure $P_{i}$; set of different categories of information features $K_{i}$, degree of change their set with different types of interaction elements and infrastructure $\left(I_{i}\right)$ internal environment $\left(S_{i}\right)$ of individual participant (agent) $\alpha_{i}$. Structure $P_{i}$ can be presented as (2): 


$$
P_{i}=\{D, N, V, S, T, U, M, F\},
$$

where $D$ is the profile of the organization's activities (business area); $N$ - the set of technological directions of activity; $V$ - plurality of activities; $S$ - structure of information support; $T$ - set of thematic directions; $U-$ set of participants; $M$ - set of target markets; $F$ - the set of financial provision (financial model).

Accordingly, you can formulate the criteria for participation in the network. Accordingly, the total effect can be calculated by the formula (3):

$$
\operatorname{Sum} \mathrm{E}=\sum_{l=1}^{L} \sum_{i=1}^{N} \sum_{j=1}^{M}\left(E_{l}\left(\left(I S_{i j}\right) \cup\left(I S_{i j}\right)\right)-T r_{l}-T_{l}\right)=\sum_{i=1}^{N} \sum_{j=1}^{M} \sum_{k=1}^{K}\left(E_{l} E\left(\left(I E_{k i j}\right) \cup\left(I E_{k i j}\right)\right)-T r_{l}-T_{l}\right)
$$

where Sum $E$ - total effect of integration in the innovation network; $E_{l}$ - effect of participation in the network $l ; r_{l}$ - transaction costs of the institute of administrative barriers; $T_{l}$ - transformation costs of the industry (sectors) in which they operate $I E_{\mathrm{kij}}$.

By further empirically examining these models, we hope to produce a more complete understanding of network structures in different sectors.

\section{Conclusions}

In modern conditions, it becomes necessary to develop guidelines for development the national innovation systems and assessing their role in the implementation of innovation policy and ensuring sustainable national socio-economic development. In the conditions of transition to a new technological order, innovation development strategies should be focused on ensuring the competitiveness of economic entities, which can be done through innovation networks. We feel that our study enhances academic understanding of the factors of innovation transformation of economic system based on the formation and distribution of innovation networks corresponding to the promising trends of modern scientific and technological development, designed to ensure the involvement of a large number of innovation system agents that contribute to the implementation of structural changes.

The foregoing discussion has attempted to analysis of characteristics of innovation networks, a methodology for assessing the innovation potential of innovation networks in the economic system based on indicators of the quantitative composition (dynamics) and dynamics of innovation potential to substantiate the viability of this organizational form in developing sectoral policies and highlighting technological priorities has been developed. The developed economic and mathematical model of management of innovation network leads us to the conclusion that allows predict changes and form a targeted impact on factors when creating new intersectoral structures in order to increase the volume of innovation products.

Our study serves as a window to an understanding of the process in technology transfer network, model of which was designed to unite the totality of functioning core enterprises, a number of scientific and educational institutions, as well as infrastructure to achieve a synergistic effect throughout the value chain of innovation products. Clearly some of given propositions we have offered are not entirely unique but the paper contains clarifications and additions to theoretical aspects in the field of innovation networks management and systems analysis to the development of economy, etc. However, we submit that the contribution of our paper rests on applying the developed methodology for assessing the potential for the development of innovation networks in the formation of strategic plans for economic system development and the selection of models for the implementation policy of innovation priorities. In addition, the economic and mathematical models and collected base for evaluating innovative networks can be used in managing the innovation development of the economy.

\section{Acknowledgements}

The publication is funded by Ministry of Education and Science of Ukraine within the research project № 0117 U003855 «Institutional and technological design of innovation networks for Ukraine national security systemic providing» and research project «Development of scientific and methodological foundations and practical tools for evaluating of the product innovations commercial (market) prospects». 


\section{References}

[1] J. Alstott, Triulzi, G., Bowen, Y., Luo J., "Mapping Technology Space by Normalizing Patent Networks," Scientometrics, vol. 110 (1), pp. 443-479, 2017. Available from: https://doi.org/10.1007/s11192-016-2107-y

[2] V. Babenko, "Formation of economic-mathematical model for process dynamics of innovative technologies management at agroindustrial enterprises, " Actual Problems of Economics, vol. 139, iss. 1, pp. 182-186, 2013.

[3] Th. Clauss, P. Spieth, "Governance of open innovation networks with national vs international scope, " Journal of Strategy and Management, vol. 10, iss. 1, pp. 66-85, 2017. Available from: https://doi.org/10.1108/JSMA-07-2015-0057

[4] Cornell University, INSEAD, and WIPO. The Global Innovation Index 2018: Energizing the World with Innovation. Ithaca, Fontainebleau, and Geneva. Available from: https://www.wipo.int/edocs/pubdocs/en/wipo_pub_gii_2018.pdf [Accessed 4th December 2018].

[5] M. Daly, "The effect of participation in Denmark's Innovation Network program," Economics of Innovation and New Technology, vol. 27 (5-6), pp. 454-478, 2018. Available from: https://doi.org/10.1080/10438599.2017.1374045

[6] B. Droste-Franke, G. Fohr, "Simulating Innovation of Key technologies in German Energy Transition," Social Simulation Conference (SSC), ESSA, 25-29 September 2017, Dublin; 2017.

[7] G. Ferraro, A. Iovanella, "Organizing collaboration in inter-organizational innovation networks, from orchestration to choreography," Int. J. Eng. Bus. Mngt, vol. 7 (24), pp. 1-14, 2015. Available from: https://doi.org/10.5772/61802

[8] G. Ferraro, A. Iovanella, "Technology transfer in innovation networks: An empirical study of the Enterprise Europe Network," International Journal of Engineering Business Management. 2017. Available from: https://doi.org/10.1177/1847979017735748

[9] G. Fohr, B. Droste-Franke, "Analysing and Visualising Innovation Networks of Key Enabling Technologies in the German Energy Transition," Third European Conference on Social Networks (EUSN) 26-29 September 2017, Mainz; 2017.

[10] Innovation Development Programmes of Russian State-Owned Companies: Interim Results and Priorities. L. Gokhberg, A. Klepach, P. Rudnik et al. (eds.); National Research University Higher School of Economics. Moscow: HSE; 2015.

[11] Joint Project: Network Analysis and Simulation of Innovation Dynamics for new Key Technologies in the Energy Sector (InnoSEn). Available from: https://www.ea-aw.org/research/overview/innosen.html [Accessed 4th December 2018].

[12] A. Kaufmann, P. Lehner, F. Tödtling, "Effects of the Internet on the spatial structure of innovation networks," Information Economics and Policy, vol. 15, pp. 402-424, 2003. Available from: https://doi.org/10.1016/S0167-6245(03)00005-2

[13] Q. Long, Sh. Li, "The innovation network as a complex adaptive system: flexible multi-agent based modeling, simulation and evolutionary decision making," The International Conference on Intelligent Systems Design and Engineering Applications (ISDEA 2014). Zhangjiajie, China 15-16 June 2014 IEEE; 2014.

[14] Y. Mishenin, I. Koblianska, V. Medvid, Y. Maistrenko, "Sustainable regional development policy formation: role of industrial ecology and logistics," Entrepreneurship and Sustainability Issues, vol. 6 (1), pp. 329-341, 2018. Available from: https://doi.org/10.9770/jesi.2018.6.1(20)

[15] R. Morrar, F. Gallouj, H. Hammadou, "Public-private innovation networks and innovation activities in French service firms," Journal of Innovation Economics \& Management, vol. 10 (2), pp. 191-217. 2012. Available from: https://doi.org/10.3917/jie.010.0191

[16] S. Najafi-Tavani, Z. Najafi-Tavani, P. Naudé, et al., "How collaborative innovation networks affect new product performance: Product innovation capability, process innovation capability, and absorptive capacity," Industrial Marketing Management, vol. 73, pp. 193-205, 2018. Available from: https://doi.org/10.1016/j.indmarman.2018.02.009 
[17] T. S. Novikova, "Problems of evaluating the effectiveness of investment projects of public-private partnership," Russian Economic Congress. New Econ. Association, RAS Institute of Economics; 2009.

[18] V. Omelyanenko, I. Semenets-Orlova, O. Khomeriki, L. Lyasota, Y. Medviedieva, "Technology transfer management culture (education-based approach)," Problems and Perspectives in Management, vol. 16 (3), pp. 454-463, 2018. Available from: https://doi.org/10.21511/ppm.16(3).2018.36

[19] V. Omelyanenko, D. Volodin, "Nanoinformatics application framework for R\&D and industrial analisys," 2017 IEEE 7th International Conference Nanomaterials: Application \& Properties: 01NNPT03-1-01NNPT03-4; 2017. Available from: https://doi.org/10.1109/NAP.2017.8190183

[20] O. Prokopenko, O. Kudrina, V. Omelyanenko, "Analysis of ICT Application in Technology Transfer Management within Industry 4.0 Conditions (Education Based Approach)," CEUR Proceedings, Vol2105, pp. 258-273, 2018.

[21] O. Prokopenko, V. Omelyanenko, J. Klisinski, "Innovation policy development conceptual framework for national resource security providing," Journal of Environmental Management and Tourism, vol. 9, no. 5, pp. 1099-1107, 2018. Available from: https://doi.org/10.14505//jemt.v9.5(29).23

[22] Sh. Purchase, D. Olaru, S. Denize, "Innovation network trajectories and changes in resource bundles," Industrial Marketing Management, Vol. 43, Iss. 3, pp. 448-459, 2014. Available from: https://doi.org/10.1016/j.indmarman.2013.12.013

[23] G. Rampersad, P. Quester, I. Troshani, "Managing innovation networks: Exploratory evidence from ICT, biotechnology and nanotechnology networks," Industrial Marketing Management, Vol. 39, Iss. 5, pp. 793-805. 2010. Available from: https://doi.org/10.1016/j.indmarman.2009.07.002

[24] REN 21. Renewables 2017 Global Status Report. Paris: REN21 Secretariat. Available from: http://www.solarthermalworld.org/sites/gstec/files/news/file/2017-06-

22/170622_gsr_2017_full_report_final.pdf [Accessed 4th December 2018].

[25] M. Sartas, M. Schut, F. Hermans, Pv. Asten, C. Leeuwis, "Effects of multi-stakeholder platforms on multi-stakeholder innovation networks: Implications for research for development interventions targeting innovations at scale, " PLoS ONE, vol. 13 (6), pp. e0197993, 2018. Available from: https://doi.org/10.1371/journal.pone.0197993

[26] L. N. Semerkova, T. I. Sherstobitova, "Formation of the mechanism of benchmarking interaction of enterprises in the sphere of innovation activity," Moscow: SIC INFRA-M; 2018.

[27] V., Babenko, O., Nazarenko, I., Nazarenko, O., Mandych, "Aspects of program control over technological innovations with consideration of risks", Eastern-European Journal of Enterprise Technologies, Vol. 3/4 (93), pp. 6-14, 2018. DOI: 10.15587/1729-4061.2018.133603

[28] A. Vermeij, "Apple's Internal Innovation Network Unraveled. Part 1. Evolving Network," Available from: http://www.kenedict.com/apples-internal-innovation-network-unraveled-part-1-evolving-networks/ [Accessed 4th December 2018].

[29] X. F. Wang, G. Chen, "Complex networks: small-world, scale-free and beyond," IEEE Circuit Syst Mag, vol. 3 (1), pp. 6-20, 2003.

[30] F. Wei, D. Sheng, W. Lili, "Evolutionary Model and Simulation Research of Collaborative Innovation Network: A Case Study of Artificial Intelligence Industry," Discrete Dynamics in Nature and Society, vol. 2018, 2018. Available from: https://doi.org/10.1155/2018/4371528

[31] O. Williamson, "The Economic Institutions of Capitalism Firms, Markets, Relational Contracting," The Free Press, New York; 1985.

[32] V., Babenko, Yu., Romanenkov, L., Yakymova, A., Nakisko, "Development of the model of minimax adaptive management of innovative processes at an enterprise with consideration of risks", EasternEuropean Journal of Enterprise Technologies, Vol. 5, No. 4 (89), pp. 49-56, 2017. DOI: https://doi.org/10.15587/1729-4061.2017.112076

[33] I. Daugule, A. Kapenieks, "Knowledge flow analysis: the quantitative method for knowledge stickiness analysis in online course," Periodicals of Engineering and Natural Sciences, vol. 7, no. 1, pp.165-171, 2019. Available from: http://dx.doi.org/10.21533/pen.v7i1.358.g250 
[34] B. Durakovic, "Design for Additive Manufacturing: Benefits, Trends and Challenges," Periodicals of Engineering and Natural Sciences, vol. 6, no.2, pp. 179-191, 2018. Available from: http://dx.doi.org/10.21533/pen.v6i2.224.g208

[35] V., Babenko, N., Chebanova, N., Ryzhikova, S., Rudenko, N., Birchenko, "Research into the process of multi-level management of enterprise production activities with taking risks into consideration", EasternEuropean Journal of Enterprise Technologies, Vol. 1, No 3 (91), pp. 4-12, 2018. DOI: 10.15587/17294061.2018.123461

[36] W. Zhou, N. Koptyug, S. Ye., Y. Jia, X. Lu, "An Extended N-Player Network Game and Simulation of Four Investment Strategies on a Complex Innovation Network," PLOS ONE, vol. 11(1), pp. e0145407, 2016. Available from: https://doi.org/10.1371/journal.pone.0145407

[37] S. Ulubeyli, A. Kazaz, V. Arslan, "A Structured Selection Process for Small and Medium Enterprises in Construction Industry: Case of International Projects," Periodicals of Engineering and Natural Scinces, vol. 5, no. 3, pp. 263-270, 2017. Available from: http://dx.doi.org/10.21533/pen.v5i3.95.g139 